\title{
Expression of p73 and Reelin in the Developing Human Cortex
}

\author{
Gundela Meyer, ${ }^{1}$ Carlos Gustavo Perez-Garcia, ${ }^{1}$ Hajnalka Abraham, ${ }^{1}$ and Daniel Caput ${ }^{2}$ \\ 1Department of Anatomy, University La Laguna, 38071 Tenerife, Spain, and 2Sanofi Recherche, Innopole, BP 13731676 \\ Labège CEDEX, France
}

Cajal-Retzius (CR) cells of the developing neocortex secrete Reelin (Reln), a glycoprotein involved in neuronal migration. CR cells selectively express p73, a p53 family member implicated in cell survival and apoptosis. Immunocytochemistry in prenatal human telencephalon reveals a complex sequence of migration waves of p73- and Reln-immunoreactive (IR) neurons into the cortical marginal zone (MZ). At early preplate stages, p73/ Reln-IR cells arise in distinct sectors of the telencephalon, including cortical primordium and ganglionic eminences. After the appearance of the cortical plate, further p73/Reln-IR cells originate in the medial periolfactory forebrain. In addition, p73 marks a novel cell population that appears at the choroidcortical junction or cortical hem before the emergence of the dorsal hippocampus. A pronounced mediolateral gradient in the density of p73/Reln-IR neurons in the neocortical MZ at 8 gestational weeks suggests that a subset of CR cells migrate

The extracellular matrix glycoprotein Reelin (Reln) is critically involved in the control of neuronal migration. In the developing cerebral cortex, it is expressed by Cajal-Retzius (CR) cells in the marginal zone (MZ) (D'Arcangelo et al., 1995, 1997). CR cells appear early in development; in human, they form a large pleomorphic cell family characterized by a horizontal axonal plexus and Reln expression (Meyer et al., 1999). Rodent CR cells are more uniform; they are usually bipolar and horizontally oriented (Del Rio et al., 1995). Cortical development requires precise synchronization of radial and tangential migration streams. Projection neurons are born in the pallial ventricular zone (VZ) and migrate radially into the cortical plate (CP), whereas most GABAergic interneurons migrate tangentially from ganglionic eminences (Anderson et al., 1997, 2001; Parnavelas 2000). CR cells were proposed to derive from the retrobulbar basal forebrain and invade the marginal zone (MZ) through tangential migration (Meyer and Wahle, 1999; Zecevic and Rakic, 2001). The targets of the Reln-signal are the neurons in the CP that express the cytoplasmic adapter protein disabled 1 (Dab1) (Howell et al., 1997). Absence of Reln or Dab1 results in a reeler phenotype (D’Arcangelo et al., 1995; Sheldon et al., 1997), characterized by an inverted cortical migration gradient and abnormal cytoarchitecture (Lambert de Rouvroit and Goffinet, 1998). Hu-

Received Nov. 20, 2001; revised March 7, 2002; accepted April 4, 2002

This work was supported by Grant EU "Concorde" (QLG3-CT2000-30158) (G.M.). C.G.P.G. is supported by the Ministerio de Educacion, Cultura y Deportes, Spain. We thank Jacques Bonnin for technical assistance wity in situ hybridization Dr. André Goffinet for the generous gift of antibodies 142 and G10.

Correspondence should be addressed to Dr. Gundela Meyer, Department of Anatomy, Faculty of Medicine, University La Laguna, 38071 La Laguna Tenerife, Spain. E-mail: gmeyer@ull.es.

Copyright (C) 2002 Society for Neuroscience $\quad 0270-6474 / 02 / 224973-14 \$ 15.00 / 0$ tangentially from cortical hem and taenia tecta into neocortical territory. This hypothesis is supported by the absence of p73transcripts in prospective neocortex of p73-/-mice at embryonic day 12 (E12), whereas they are present in cortical hem and taenia tecta. In the p73-/- preplate, Reln is faintly expressed in a calretinin-positive cell population, not present in this form in the E12 wild-type cortex. At P2, Reln-IR CR cells are undetectable in the p73-/- cortex, whereas Reln-expression in interneurons is unchanged. Our results point to a close association between p73 and Reln in CR cells of the developing neocortex, with a partial dissociation in early preplate and basal telencephalon, and to a p73-mediated role of the cortical hem in neocortical development.

Key words: Cajal-Retzius cells; basal telencephalon; cortical hem; taenia tecta; p73-/- mutant; Reelin man reelin mutations cause lissencephaly and malformations of the cerebellum (Hong et al., 2000).

p73 belongs to the family of the tumor-suppressor protein p53. Differential splicing and alternate promoter usage give rise to several p73 isoforms (Kaghad et al., 1997; Yang et al., 2000); $\alpha$ and $\beta$ isoforms induce apoptosis (Jost et al., 1997), whereas truncated isotypes $(\Delta \mathrm{Np} 73)$ lacking the transactivation domain have anti-apoptotic properties (Pozniak et al., 2000). To date, only $\mathrm{p} 73 \alpha$ variants were found in developing mouse (Yang et al., 2000) and human (D. Caput, unpublished observations) brains. p $73 \alpha$ and $\Delta$ Np $73 \alpha$ expression takes place in few but characteristic sites including CR cells in neocortex and archicortex, neurons in the hypothalamus, and epithelium of the choroid plexus. In p73deficient mice, CR cells are absent in the perinatal MZ; the cortex presents no major structural abnormalities, but the development of dentate gyrus is severely affected (Yang et al., 2000).

In the developing human brain, the Reln signal is particularly prominent (Meyer and Goffinet, 1998; Meyer, 2001). In the present study, we explore the relationship between Reln and p73, a protein whose roles in the developing cortex are as yet completely unknown. We are particularly interested in the question of whether p73 is a more specific marker of CR cells than Reln, which is widely expressed in the CNS (Schiffmann et al., 1997), and thus learn more about the possible origins and migration pathways of $\mathrm{CR}$ cells and their possible activity in cortical migration.

\section{MATERIALS AND METHODS}

Immunohistochemistry using anti-p73 and anti-Reln antibodies was performed in 48 embryonic and fetal human brains, obtained from spontaneous or legal abortions, following national guidelines in Spain, and supervised by the ethics committee of the University Hospital La La- 
guna. The embryonic material, 5-8 gestational weeks (GW) old, was classified according to Carnegie stages (CS) ( $\mathrm{O}^{\prime}$ Rahilly and Müller, 1994). One case of each of the following stages was examined (approximate gestational age in parentheses): 16 (5 GW); 16/17 (5.5 GW); 17 (6 $\mathrm{GW}) ; 17 / 18$ (6 GW); 18 (6.5 GW); 19 (6.5 GW); 20 (7 GW); 21 (7GW); $22(8 \mathrm{GW})$ (Meyer et al., 2000). Fetal brains aged 9 to $40 \mathrm{GW}(9,10,11$, $12,13,14,15,16,17,18,19,20,21,22,23,25,27,28,29,31,34,38$, and $40 \mathrm{GW}$ ) were fixed in Bouin or Carnoy, embedded in paraffin, and cut into $10-\mu \mathrm{m}$-thick sections. Sections from the temporal lobe of infant and adult brains aged 2, 3, 5, and 6 months and 16, 26, 43, and 57 years were also examined.

In addition, we studied C57B/6 mice at embryonic day 13 (E13), E15, E16, E18, and postnatal day 6 (P6), P8, and P20. The brains were fixed in Bouin, embedded in paraffin, and cut into serial sections of $10 \mu \mathrm{m}$. We also examined E9.5 and E12 p73-/- mutant mice (Yang et al., 2000) and wild-type littermates that were initially fixed in $4 \%$ paraformaldehyde, postfixed in Bouin, embedded in paraffin, and serially cut at $5 \mu \mathrm{m}$ in a coronal plane. Sections of $\mathrm{p} 73-/-$ and wild-type mice at $\mathrm{P} 2$, processed for Reln in situ hybridization and immunohistochemistry, and described previously (Yang et al., 2000), were re-examined.

Human and mouse brain sections were incubated in the primary antibodies overnight in a humid chamber. After rinsing, they were incubated in the corresponding biotinylated secondary antibodies (rabbit anti-mouse IgG or goat anti-rabbit IgG; Dako, Glostrup, Denmark), diluted 1:200 in Tris-buffered saline (TBS), washed, and incubated in the ABC complex (Dako). Bound peroxidase was revealed using $0.05 \%$ 3,3'-diaminobenzidine (DAB; Sigma, St. Louis, MO), 0.04\% ammonium nickel (II) sulfate, and $0.03 \%$ hydrogen peroxide in TBS, $\mathrm{pH} 7.6$. The sections were dehydrated, cleared, and covered with Eukitt (O. Kindler GmbH, Freiburg, Germany).

The rabbit polyclonal anti-p73 $\alpha$ antibody used was described elsewhere (Kaghad et al.,1997); the mouse monoclonal anti-p $73 \alpha / \beta$ (antibody-2, clone ER-15) was purchased from NeoMarkers (Fremont, CA). The mouse monoclonal anti-Reln antibodies G10 and 142 (de Bergeyck et al.,1998) were a gift of A. Goffinet.

Double immunostaining (p73 is expressed in the nucleus, Reln in the cytoplasm) was systematically performed to study p73 and Reln in the same section. After the first primary antiserum (anti-p73; diluted 1:150), sections were incubated in the corresponding anti-rabbit secondary antibody and processed with DAB and ammonium nickel sulfate as described above, which yielded a black reaction product. After thorough rinses, the sections were incubated overnight in the second primary antibody, anti-Reln, 1:500. The secondary antibody was in this case the corresponding goat anti-mouse IgG. After washing, the sections were immersed in $0.05 \%$ DAB in TBS, $\mathrm{pH} 7.6$; the reaction product appeared brown.

p73 immunohistochemistry required pretreatment of 15 min boiling in citrate buffer, pH 6.0; in some embryonic human brains, this treatment was incompatible with further immunostaining for Reln because the fragile tissue disintegrated. In these cases, adjacent sections were individually stained for p73 and Reln.

To visualize Reln immunoreactivity in the cortical primordium of the p73-/-mice, we used an antigen retrieval protocol of $15 \mathrm{~min}$ boiling in citrate buffer, $\mathrm{pH}$ 6.0, followed by $5 \mathrm{~min}$ incubation in a solution of $0.1 \%$

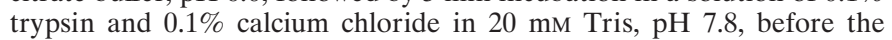
application of the primary antibody. In the E12 mice, calretinin immunostaining was performed using a rabbit polyclonal antibody (Swant, Bellinzona, Switzerland), diluted 1:2000. Double immunostaining p73/ calretinin was done as described above for p73/Reln.

In situ hybridization for p73 in paraffin sections: Paraffin was removed with xylene followed by rehydration and transfer of the sections into sterile $2 \times$ SSC. Sections were then processed for in situ hybridization (ISH). ${ }^{35}$ S-UTP labeled RNA probes were generated by in vitro transcription (T7 Promega kit; Promega, Madison, WI) of RT-PCR fragments derived from total mouse brain RNA using specific primers. [5'<T7-TGCTGAGCAAATAGAACTGGG and 5'<AATGAGCGGCAGCGTTGGG]. Hybridization conditions were previously described elsewhere (Yang et al., 2000).

\section{RESULTS}

\section{Cajal-Retzius cells in the human marginal zone} specifically express $p 73$

We systematically examined coexpression of p73 and Reln during the period of cortical migration. In the initial stages of the $\mathrm{CP}$, from 8 to $12 \mathrm{GW}$, most CR cells coexpressed p73 and Reln (Fig. 1A). A few p73-immunonegative, Reln-immunopositive cells (Fig. $1 B$ ) were found in lateral cortical regions, but were not detected in older brains. At this stage, CR cells displayed large horizontal somata close to the pial surface.

The number and morphological diversity of p73/Relnimmunoreactive (IR) CR cells increased from $14 \mathrm{GW}$ onward (Fig. $1 C$ ), concurrent with the appearance of the subpial granular layer (SGL). The SGL was most prominent from 16 to $24 \mathrm{GW}$ (Meyer and Gonzalez-Hernandez, 1993; Meyer and Goffinet, 1998; Meyer and Wahle, 1999). During this period, virtually all Reln-IR cells in the neocortical MZ had p73-IR nuclei; vice versa, virtually all ( $\sim 94 \%)$ p73-IR cell nuclei had a Reln-IR cytoplasm. Both proteins were thus coexpressed by the same cell populations, most of which displayed the distinctive morphologies of CR cells. Initially, at 14-16 GW, also small granular cells were occasionally p73/Reln-IR (Fig. 1C, arrow), but thereafter, the immense majority of SGL-granule cells were negative for $\mathrm{p} 73$ and Reln (Fig. 1D). Around midgestation, p73/Reln-IR CR cells were observed at deeper levels of the MZ and developed vertically oriented somata and ascending processes (Fig. 1D,E).

After midgestation, deep vertical p73/Reln-IR CR cells displayed cytoplasmic vacuoles (Fig. $1 F$, arrows) and loss of processes, interpreted as symptoms of degenerative decline. They disappeared from the cortex during the last weeks of gestation, indicating that degeneration was followed by cell death. In parallel, an additional CR cell population differentiated in a more superficial position, often immediately beneath the pia (Fig. $1 G, H)$. These large subpial neurons represent a perinatal variety of the CR cell family (Cajal, 1911; Meyer et al., 1999); they coexpressed p73 and Reln (Fig. $1 H$ ).

From $28 \mathrm{GW}$ onward, small Reln-IR cells appeared all over the MZ (Fig. 1G, arrows). Their nuclei were much smaller than those of CR cells, and their cytoplasm was only weakly Relnimmunopositive (Fig. 1H, arrows). In contrast to CR cells, they did not express p73. Small Reln-positive, p73-negative cells increased in number after birth and persisted throughout life as Reln-IR interneurons of layer I (Fig. 1I), which are abundant in adult human cortex (Perez-García et al., 2001).

The p73/Reln-IR subpial CR neurons decreased in number after birth, and few double-positive cells remained in the infant and adult cortex (Fig. 1J-L). Their morphology was rather unconspicuous; they were usually small, sometimes horizontally oriented, without obvious signs of degeneration.

In sum, the CR cells that dominate the neocortical MZ during the period of massive cortical migration virtually completely coexpress p73 and Reln. In the developing cortex, p73 is thus specific to CR cells, whereas later-appearing Reln-positive interneurons of layer I are p73-negative.

\section{The origins of $\mathbf{p 7 3 / R e e l i n - e x p r e s s i n g ~ c e l l s ~}$}

\section{The embryonic cortical neuroepithelium and} basal telencephalon

The specificity of p73 immunostaining allowed us to trace the migratory pathways of putative CR cells from a variety of origins into the cortical primordium.

At the earliest preplate stage examined, CS 16 (5 GW), p73-IR cell nuclei were scattered throughout the telencephalon (Fig. 2A). They were most common in MZ, but sometimes appeared also in the ventricular zone (VZ). We interpreted the presence of p73-IR cells in the $\mathrm{VZ}$ as an indication that they were generated at this 


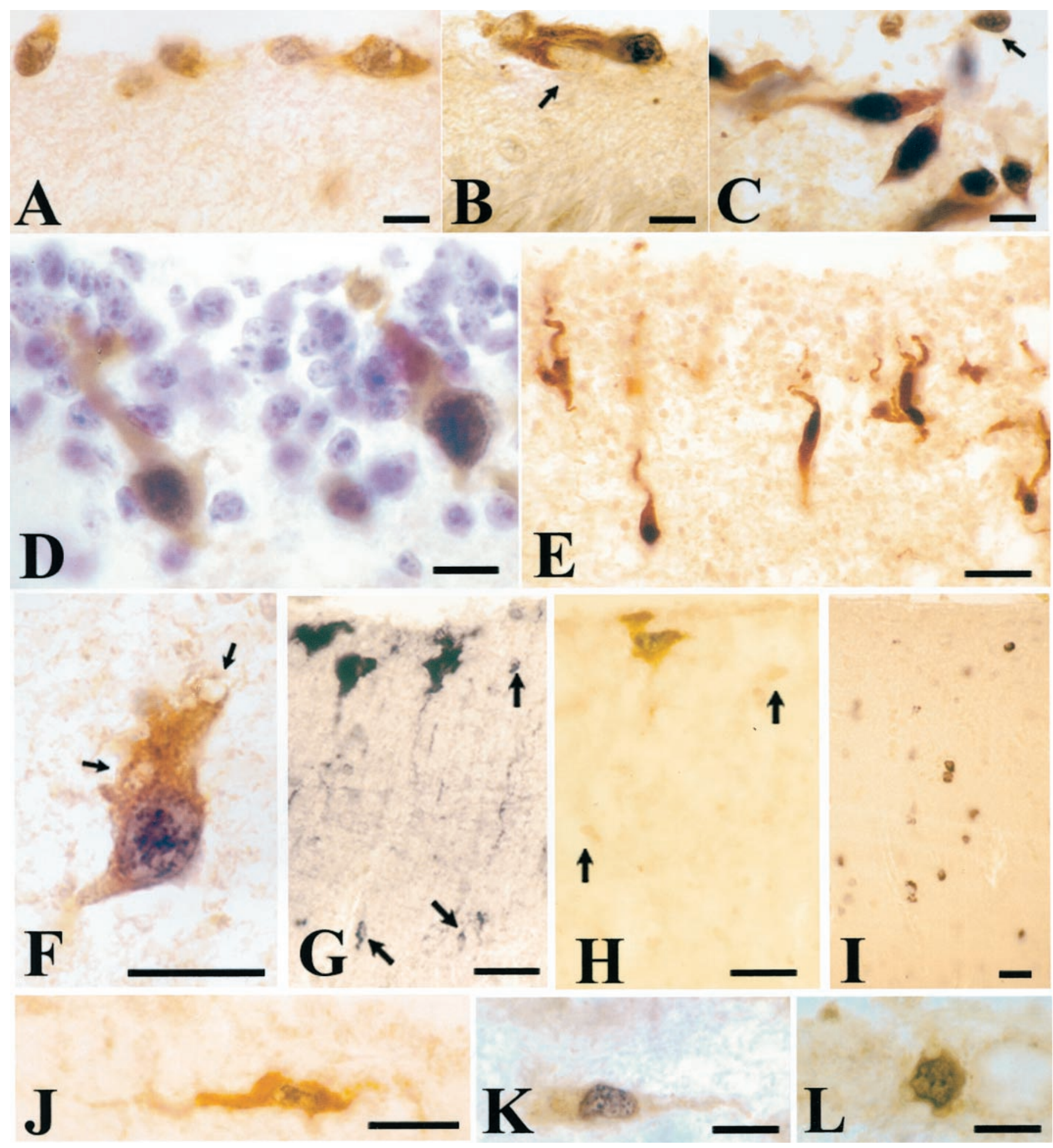

Figure 1. p73 and Reelin are coexpressed by CR cells in human neocortex. In this and the following figures, the p73 immunoreaction product is black and localized to the nucleus, whereas Reln staining is light brown or yellow and localized to the cytoplasm. The variable intensities of p73 immunostaining depend on tissue and pretreatment rather than on the age. $A, 10 \mathrm{GW}$. In the initial stages of the cortical plate, most CR cells in the MZ coexpress both proteins, although in lateral areas $(B)$ a small proportion of CR are p73-immunonegative, Reln-IR (arrow); they are not seen in older brains. $C$, 17 GW. CR cells increase in number and display a variety of shapes and orientations. At this stage, virtually all Reln-IR cells express p73. D, 20 GW. p73/Reln-IR CR cells acquire a vertical orientation and elongate soma. Cresyl violet stains the granule cells of the SGL, which are Reln- and p73-negative. E, 22 GW. CR cells descend to deeper levels of the MZ and extend long ascending processes. F, A deep CR cell at $27 \mathrm{GW}$ displays cytoplasmic vacuoles (arrows) and loss of processes, indicating degenerative decline. $G$, (Reln); H, (p73/Reln): $28 \mathrm{GW}$. A perinatal CR cell variety coexpressing p73 and Reln develops in a subpial position. In parallel, a population of small Reln-IR cells appears scattered throughout the MZ; they are p73-negative and weakly immunopositive for Reln $(G, H$, arrows). I, 43 years, Reln. Interneurons of adult layer I express Reln, but are p73-negative. $J-L$, Examples of double p73/Reln-positive neurons that are rare in postnatal life. $J, 3$ months; $K, L, 43$ years. Scale bars: $A-D, 10 \mu \mathrm{m} ; E, 25 \mu \mathrm{m} ; F, 15 \mu \mathrm{m} ; G-J, 20 \mu \mathrm{m} ; K, L, 15 \mu \mathrm{m}$. 

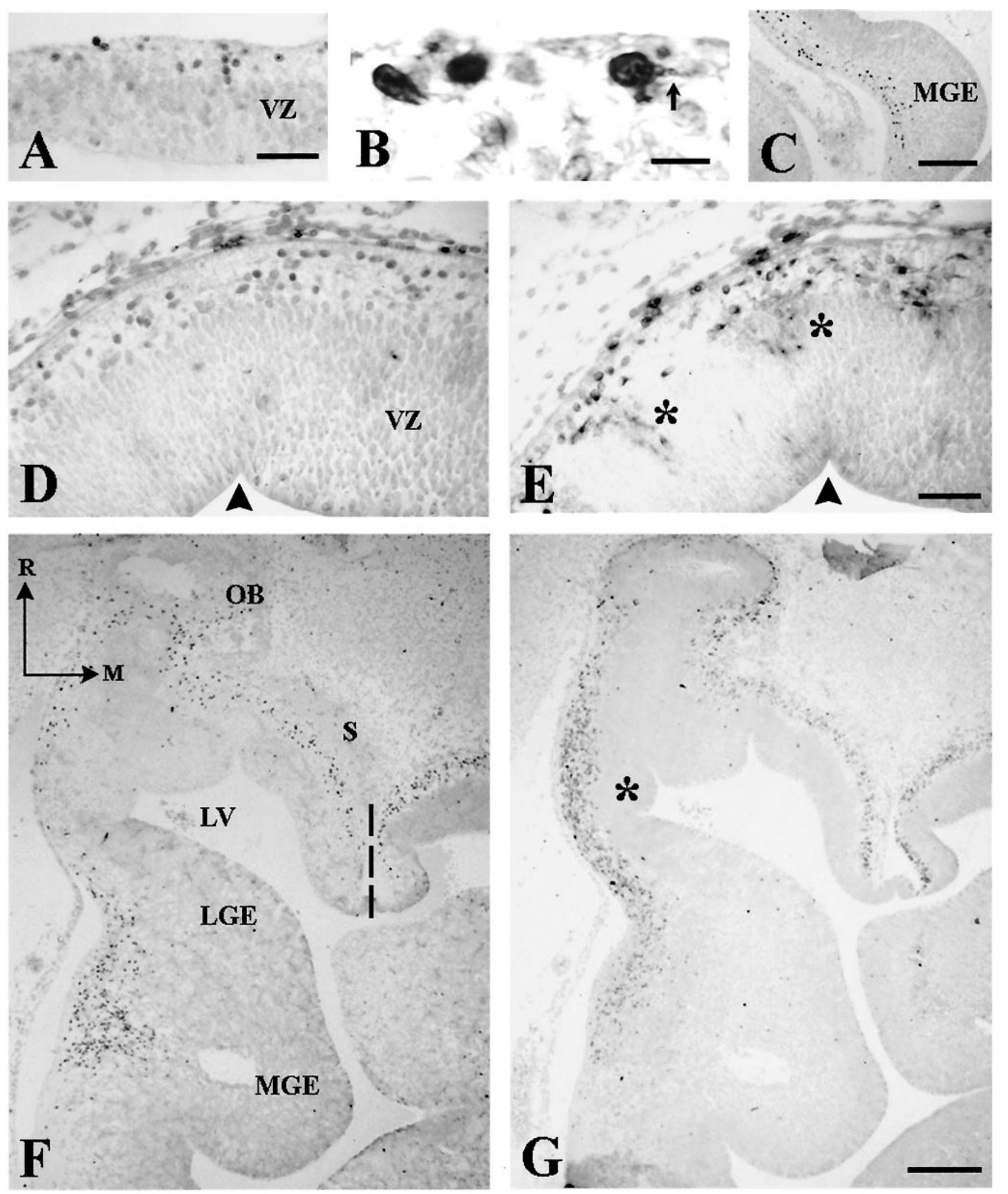

Figure 2. Early stages of human telencephalic development. $A, B$, p73-IR cells in cortical primordium at CS 16 (5.5 GW). In $B$, double staining with p73 and Reln shows processes (arrow) of cells in the incipient marginal zone. $C$, At CS 17 (6 GW), p73-IR cells extend between medial ganglionic eminence $(M G E)$ and the pial surface. $D(\mathrm{p} 73)$ and $E$ (Reln) in two adjacent sections through the rostral neocortical preplate at CS 19 (6.5 GW). p73 and Reln are partially dissociated: radial cell columns extending through the VZ are Reln-IR (asterisks), but not p73-IR. For orientation, arrowheads mark the same ventricular indentation in both sections. $F$ (p73), $G$ (Reln), Adjacent horizontal sections through the basal telencephalon at CS 19, showing a cell stream from MGE into prospective paleocortex; Reln expression is weak in MGE but increases near the pial surface. There are few p73-IR cells in lateral ganglionic eminence ( $L G E)$, compared with the high number of Reln-IR cells (asterisk). Both p73 and Reln are prominent in septum ( $S$ ) and periolfactory area. Dashed line indicates the midline. $R$, Rostral; $M$, medial. Scale bars: A, $30 \mu \mathrm{m} ; B, 10 \mu \mathrm{m} ; C, 200 \mu \mathrm{m} ; D, E, 50 \mu \mathrm{m} ; F, G, 200 \mu \mathrm{m}$. $L V$, Lateral ventricle; $O B$, olfactory bulb. 

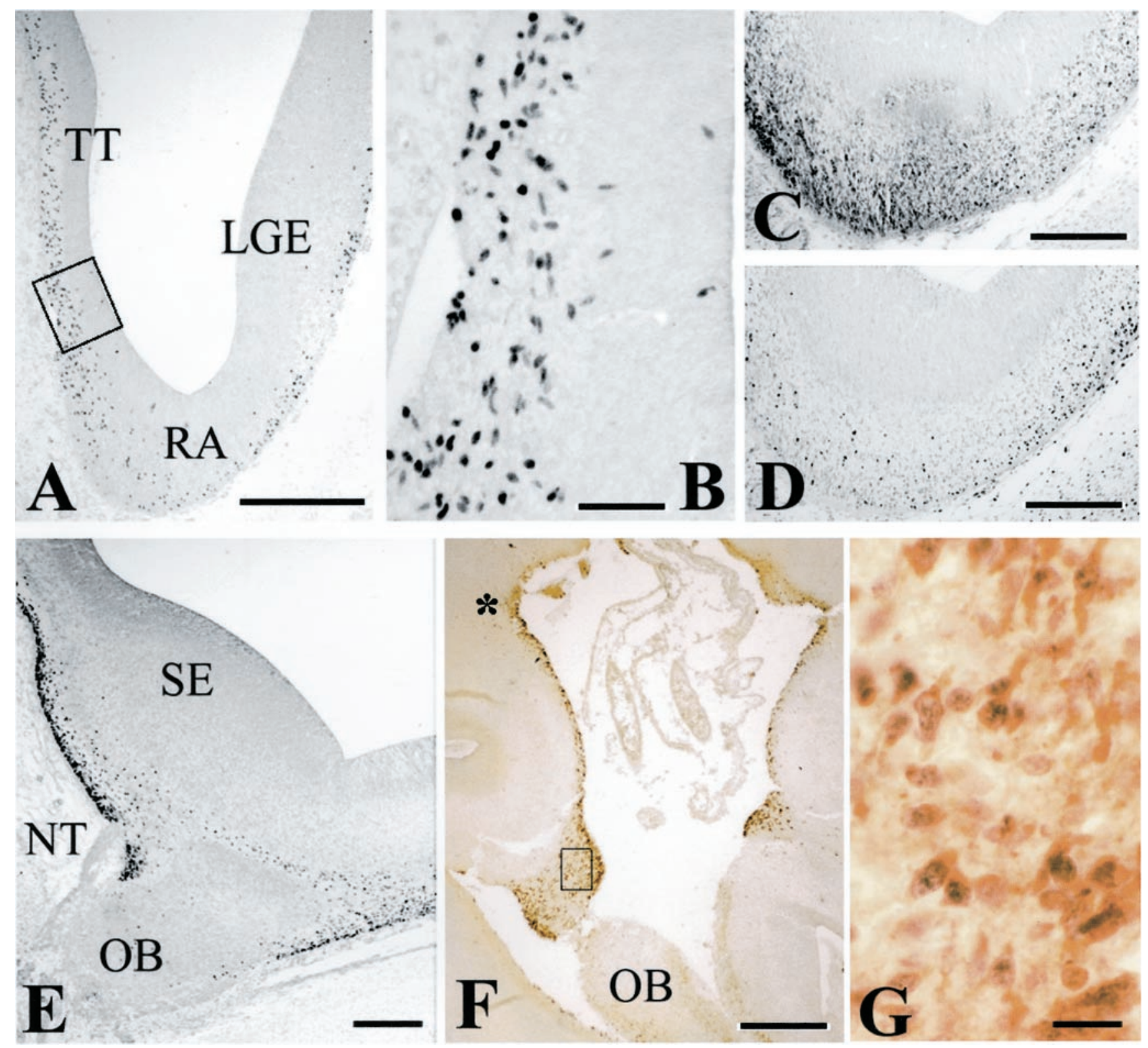

Figure 3. p73 and Reln in the periolfactory forebrain. A, CS $20(6.5 \mathrm{GW})$. Panoramic view of the retrobulbar telencephalon, with p73-IR cells in taenia tecta $(T T)$, retrobulbar area $(R A)$, and lateral ganglionic eminence $(L G E)$. B, High-power view of the boxed area in $A$, showing p73-IR cells in the VZ of TT. $C$, Reln; $D, \mathrm{p} 73, \mathrm{CS} 20$. Parallel sections through the retrobulbar area showing partial dissociation of Reln and p73 expression. $E$, CS 22 (8 GW), p73. The medial periolfactory forebrain contains numerous p73-IR cells close to the septal eminence (SE). NT, Entrance of the nervus terminalis; $O B$, olfactory bulb. F, $14 \mathrm{GW}$. Panoramic view of the medial periolfactory forebrain, double staining p 73/Reln. The asterisk marks the site where deep small p73-positive cells seem to ascend to the surface and begin to coexpress p73 and Reln. Mitral cells of the OB are Reln-positive but p73-negative. $G$, The boxed area in $F$. In the cell band surrounding the olfactory stalk, most cells coexpress p73 and Reln. Scale bars: $A, 400 \mu \mathrm{m} ; B, 50 \mu \mathrm{m} ; C-E, 200 \mu \mathrm{m} ; F$, $300 \mu \mathrm{m} ; G, 20 \mu \mathrm{m}$.

site. Reln-immunostaining was weak and confined to the MZ at CS 16 (Fig. 2C). Practically all Reln-IR cells coexpressed p73, whereas deep p73-positive cells were usually Reln-negative (data not shown).

At CS 17-19 (5.5-6.5 GW), p73 and Reln expression showed region-specific differences. In the neocortical primordium, p73-IR cells were now confined to the MZ, where they coexpressed Reln. Conversely, in the rostral cortical wall, radial columns of Reln-IR cells spanned the VZ (Fig. 2E, asterisks) (Meyer et al., 2000); adjacent sections showed that these columns were p73-negative (Fig. 2D), indicating the presence of a p73-independent Reln-IR cell population. Also at CS $17-19$, a stream of p73-IR cells extended from the medial ganglionic eminence (MGE) to the prospective paleocortex (Fig. 2C,F). Adjacent sections revealed weakly stained Reln-IR cells in the same location (Fig. $2 G$ ); they were more numerous than p73-IR cells, and their staining intensity increased toward the pial surface. In the rostral extension of the lateral ganglionic eminence (LGE), the rather sparse presence of p73-IR cells was in contrast with high numbers of Reln-IR cells (Fig. 2G, asterisk). Similarly, high numbers of Reln-IR cells compared with moderate numbers of p73-IR cells populated septum and periolfactory basal forebrain (Fig. $2 F, G$ ). Altogether, these results showed a partial dissociation of p73 and Reln in cortical preplate and embryonic basal telencephalon; 

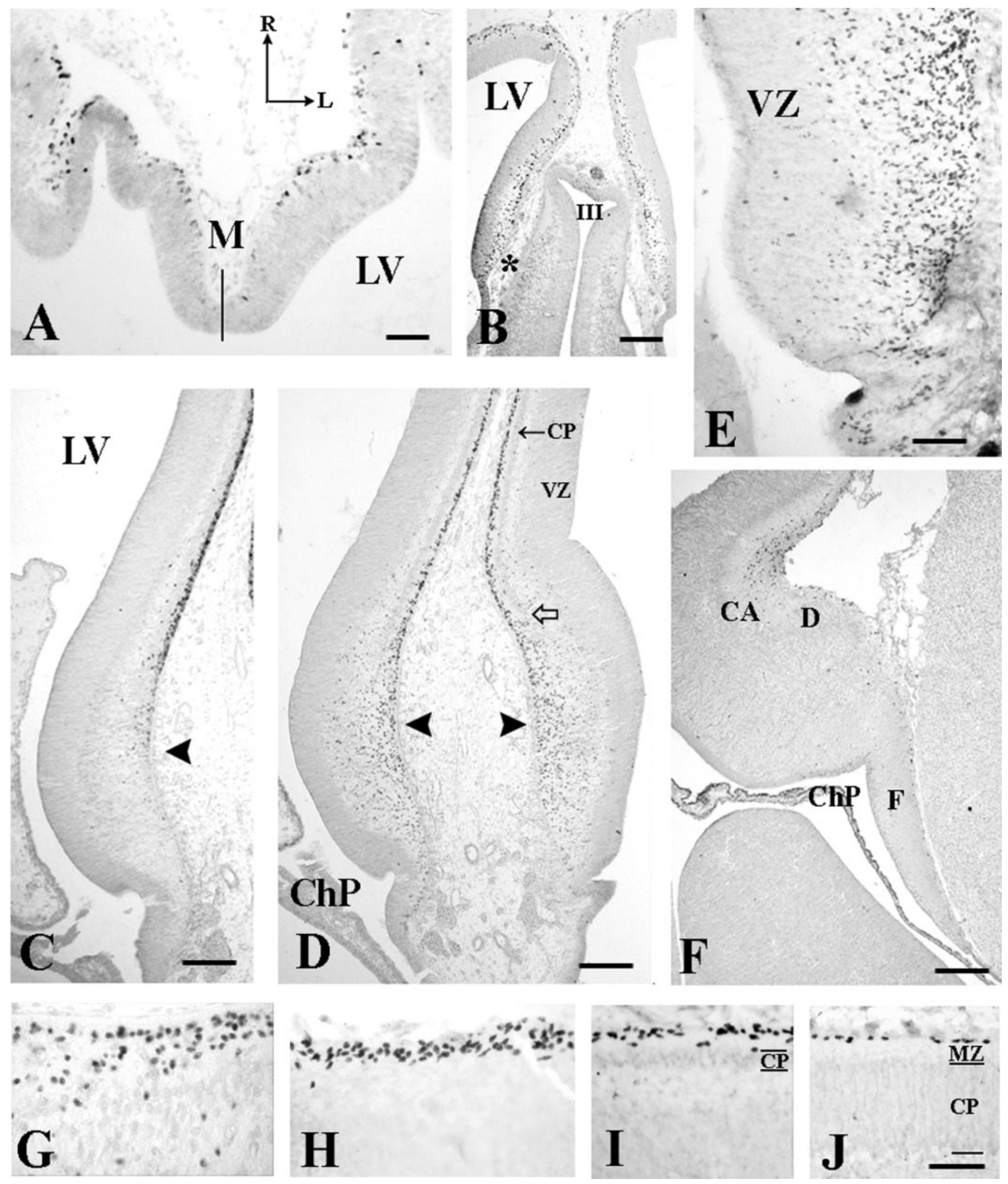

Figure 4. Evolution of p73 and Reln in the cortical hem. A, CS $17(6 \mathrm{GW})$. Horizontal section through the medial hemispheric wall. p73 expression in cortical hem is still weak, in contrast with the strong signal in the adjacent preplate. The solid line indicates the midline. $L V$, Lateral ventricle; $R$, rostral; $L$, lateral. $B$, Coronal section, CS20 (7 GW), showing p73-IR cells in the medial cerebral wall. The interface of cortical hem and choroid anlage (asterisk) is marked by numerous p73-IR cells in deep VZ. $C-E$, CS $22(8 \mathrm{GW}) . C$ (Reln) and $D(\mathrm{p} 73)$, Panoramic view of the cortical hem (arrowheads) and the adjacent cortex before the overt appearance of the hippocampus. Arrow in D indicates the cortical plate $(C P)$, open arrow the ventral edge of the CP. $E$, High magnification of the cortical hem showing large numbers of p73-IR cells in VZ and MZ. The sequence $C-E$ suggests that p73-IR cells are generated in the cortical hem, ascend to the pial surface where they begin to express Reln, and then migrate into the MZ of the adjacent (Figure legend continues.) 
although they were expressed at the same sites, Reln-IR cells usually outnumbered p73-IR cells.

\section{The periolfactory basal forebrain}

The retrobulbar forebrain, thought to give rise to the SGL (Brun, 1965; Gadisseux et al., 1992), was also proposed to be a potential source of neocortical CR cells (Meyer and Goffinet, 1998; Meyer and Wahle, 1999; Zecevic and Rakic, 2001). We thus analyzed p73 and Reln expression in the retrobulbar area at different time points.

At CS $20(6.5 \mathrm{GW})$, the periolfactory forebrain contained numerous Reln-IR cells, but p73-IR cells were rather sparse (Fig. $3 C, D)$. This situation changed at $8 \mathrm{GW}$, the age of neocortical plate formation. The number of p73-IR cells increased at the level of the septal eminence (Fig. $3 E$ ), particularly around the entrance of the nervus terminalis. Comparison with adjacent Reln-stained sections revealed a close match in distribution and number of p73-IR and Reln-IR cells (the tissue of these cases was extremely fragile and did not allow double staining).

From 10 to 16 GW, p73-positive, Reln-negative cells lay scattered in the medial periolfactory area between septum and olfactory bulb (Fig. 3F, asterisk); they seemed to course from the ventricle to the pial surface, where most cells coexpressed p73 and Reln. A broad band of p73/Reln-IR cells surrounded the stalk of the olfactory bulb (Fig. $3 F, G$ ) and merged laterally with the MZ of the adjacent olfactory cortex. From here, p73/Reln-IR cells may migrate farther into the neocortical MZ via the SGL. This route was suggested based on the density gradient of Reln-IR CR cells from paleocortex to neocortex at 13/14 GW (Meyer and Wahle, 1999).

The possible source of p73/Reln-positive cells described here in the medial periolfactory forebrain differs from that of the SGL, which appears in a more lateral position as a compact aggregate of calretinin-positive, p73 and Reln- negative granule cells (Meyer and Wahle, 1999).

\section{The cortical hem}

The cortical hem is a transient neuroepithelial structure in the dorsal telencephalon that forms a boundary between the prospective hippocampus (HC) and the choroid plexus epithelium. It is defined by the expression of multiple Wnt genes (Grove et al., 1998). In our early fetal material, the cortical hem was a major source of p73-expressing cells during a restricted time period before the appearance of the dorsal HC. We analyzed in detail the distribution of p73-IR cells in the cortical hem and their possible relationship with neocortical development during the crucial period from 7 to $10 \mathrm{GW}$.

The first p73-IR cells in the cortical hem appeared at CS 20 (7GW) (Fig. 4B). In previous stages, there was only a "choroid plaque," an invagination of the telencephalic roof, which was p73-negative (Fig. 4A). At CS $22(8 \mathrm{GW})$, just before the emergence of the dorsal $\mathrm{HC}$, we observed a dramatic increase in the number of p73-IR cells in the neuroepithelium of the cortical hem (Fig. 4D,E); p73-IR cells gathered in the wide $\mathrm{MZ}$ and then seemed to course farther into the $\mathrm{MZ}$ of the adjacent cortex. In the cortical hem, p73-IR cells were Reln-negative, and only the
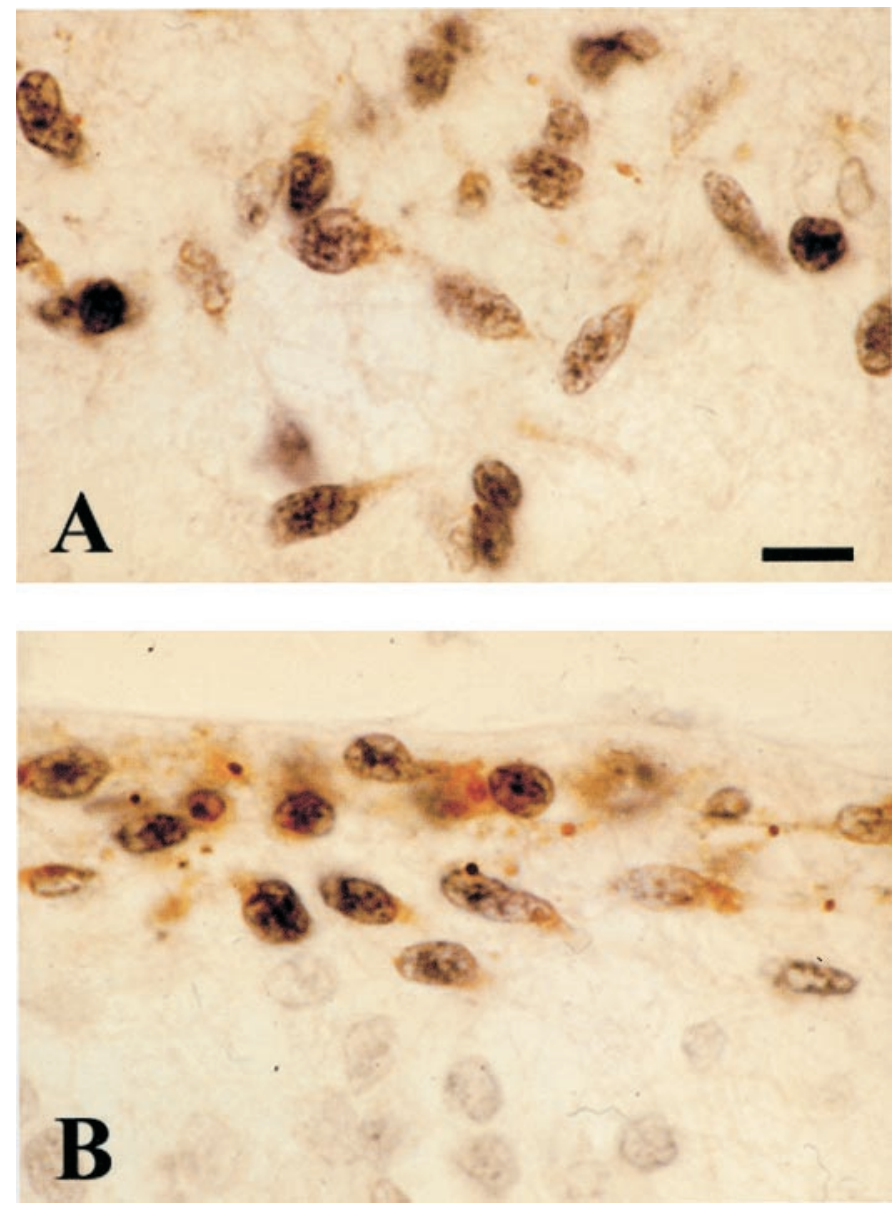

Figure 5. Expression of p73 and Reln in the cortical hem. 9 GW, double staining $\mathrm{p} 73$ and Reln. $A$, In the wide MZ of the cortical hem, p73-IR cells begin to express Reln when they approach the pial surface. $B$, In the MZ of the adjacent dorsomedial cortex, coexpression is virtually complete. Scale bar, $10 \mu \mathrm{m}$.

cells close to the pial surface began to express Reln (Figs. 4C, 5A). In the $\mathrm{MZ}$ of the adjacent cortical plate, virtually all cells coexpressed p73 and Reln (Fig. 5B). This sequence suggested that p73-IR cells were generated in the cortical hem and invaded the neocortical MZ as p73/Reln-IR CR cells. In keeping with this hypothesis, the distribution of CR cells in the 8-10 GW neocortex followed a pronounced mediolateral gradient, with the highest density at the interface of cortical hem and adjacent cortex, and the lowest cell density in lateral cortex (Fig. 4G-J).

At 9-11 GW (CS 23), the gradual emergence of hippocampal subfields was assessed with calbindin and calretinin immunostaining (G. Meyer, unpublished observations). Concurrent with the differentiation of HC, the cortical hem declined, and most p73-IR cells disappeared (Fig. 4F). A few p73-IR cells remained in the fornix area until the dorsal $\mathrm{HC}$ underwent regression around 14-16 GW. This timetable of events suggests that the presence of

(Figure legend continued.) cortex. The marked gradient in CR cell density from $G$ (medial edge of the CP) to $H$ (dorsomedial cortex), $I$ (dorsal cortex), and $J$ (lateral cortex) supports this hypothesis. $F, 14 \mathrm{GW}, \mathrm{p} 73$. The cortical hem regresses after the emergence of the dorsal hippocampus, and p73-IR cells decrease in number. $C A$, Cornu ammonis fields; $C h P$, choroid plexus; $D$, dentate anlage; $F$, fimbria/fornix. Scale bars: $A, 50 \mu \mathrm{m} ; B, 175 \mu \mathrm{m} ; C, D$, $100 \mu \mathrm{m} ; E, 50 \mu \mathrm{m} ; F, 200 \mu \mathrm{m} ; G-J, 40 \mu \mathrm{m}$. 

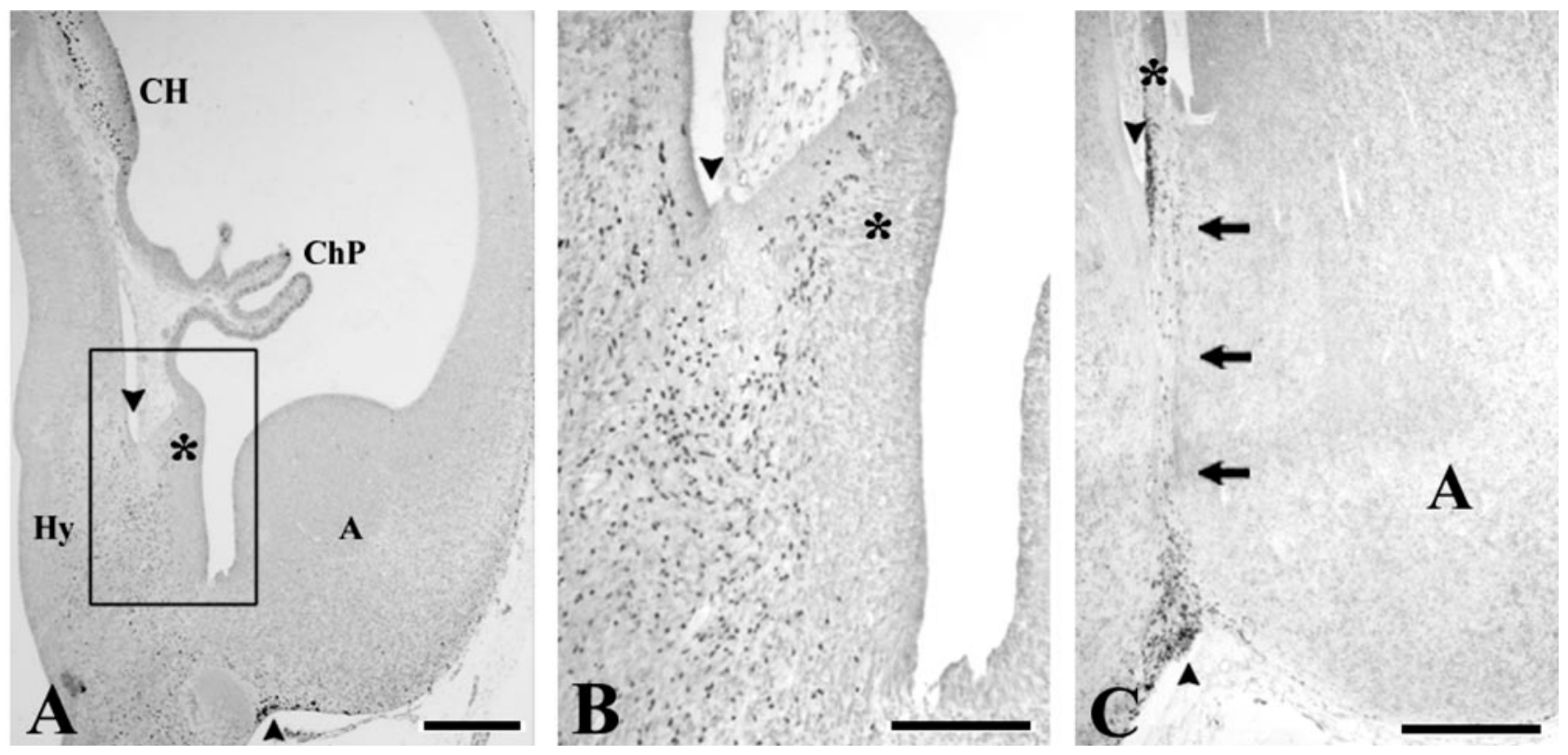

Figure 6. p73 in the strionuclear neuroepithelium. $A$, CS20 $(6.5 \mathrm{GW})$. The choroid plexus $(C h P)$ is continuous dorsally with the cortical hem $(C H)$ and ventrally with the strionuclear neuroepithelium (asterisk); the three structures display high numbers of p73-IR cells. At this stage, also the hypothalamus $(H y)$ contains a large population of p73-IR cells that seem to migrate toward the diencephalic-telencephalic boundary. $B$, The boxed area in $A$ at higher magnification. $C$, The same region at $10 \mathrm{GW}$. The strionuclear neuroepithelium (asterisk) is less prominent, and p73-IR cells are now aggregated along the diencephalic-telencephalic sulcus (arrowheads). A trail of p73-IR cells marks the boundary between hypothalamus and amygdala $(A)($ small arrows). Scale bars: $A, 300 \mu \mathrm{m} ; B, 100 \mu \mathrm{m} ; C, 250 \mu \mathrm{m}$.

p73 in the cortical hem is primarily related to the initial development of the neocortical plate rather than to the dorsal HC.

\section{p73 in other medial telencephalic centers}

p73-positive cells were also observed in the neuroepithelium of other medial telencephalic regions, suggesting further sites of generation. From CS 18 (6 GW) to $10 \mathrm{GW}$, p73-IR cells appeared in $\mathrm{MZ}$ and $\mathrm{VZ}$ of the medial hemispheric wall rostral to the choroid anlage, in a region known as taenia tecta or rostral HC (Fig. 3A,B). Only the most superficial p73-IR cells expressed Reln (data not shown). Another putative origin of p73-IR cells in embryonic and early fetal stages was at the boundary between amygdala and hypothalamus, in a small triangular eminence, the "strionuclear neuroepithelium" (Altman and Bayer, 1995). A collection of p73-IR cells appeared at CS 20 at the border between choroid plexus and strionuclear neuroepithelium, resembling a ventral counterpart of the cortical hem (Fig. 6A). From here, a trail of p73-IR cells could be followed along the diencephalic-telencephalic border to the ventral surface of the amygdala (Fig. 6A,B), merging with a similar p73-IR cell population apparently derived from the hypothalamus (Fig. 6A). Neurons coexpressing Reln and p73 were found only near the pial surface of the diencephalic-telencephalic sulcus.

The strionuclear neuroepithelium was less prominent at $10 \mathrm{GW}$ (Fig. $6 C$ ); in later fetal stages, it gave rise to the taenia of the stria medullaris, one of the attachments of the tela choroidea of the lateral ventricle. At $10 \mathrm{GW}, \mathrm{p} 73-\mathrm{IR}$ cells marked the course of the hypothalamic-amygdalar boundary (Fig. 6C, arrows); most of these cells coexpressed p73 and Reln. In older fetuses, they were no longer detected.

\section{Reelin expression in wild-type and p73-deficient mice}

To test the hypothesis that a subset of early CR cells derives from the cortical hem and migrates into neocortical territory, we studied Reln expression in p73 mutant mice in the initial stage of cortical development. We first examined expression of p73 and Reln in wild-type mice at various prenatal and early postnatal ages and confirmed that as in human brain, the two proteins were extensively coexpressed by CR cells in neocortical MZ during the main migration period from E13 to E18 (Fig. 7B). After birth, a population of Reln-positive, p73-negative interneurons appeared in layer I (Fig. 7C, arrow) and persisted into adulthood, whereas p73/Reln-IR CR cells disappeared.

No p73 and Reln expression was detected in wild-type and mutant mice at E9.5. At E12, an age comparable with human CS 20/21, most CR cells in the wild-type preplate coexpressed p73 and Reln (Fig. 7A); a few Reln-positive cells were p73-negative (see Fig. 9). High numbers of p73-IR cells were observed in cortical hem (Fig. 7D), adjacent choroid plexus anlage, strionuclear neuroepithelium and taenia tecta (Figs. $8 C, 9$ ); in these centers, the presence of p73-IR cell nuclei deep in VZ suggested local generation. In taenia tecta, superficial cells coexpressed p73 and Reln (Fig. 7G). Ventral pallium, septal eminence, and amygdala contained numerous p73-negative, Reln-positive cells in addition to double p73/Reln-positive cells (Figs. 7H, 9). Altogether, these results confirmed in mice the partial dissociation of

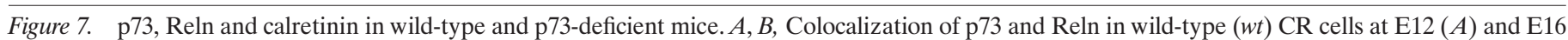

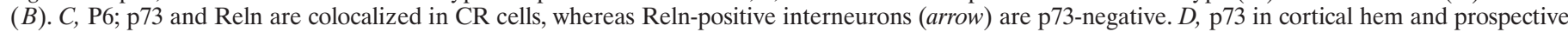

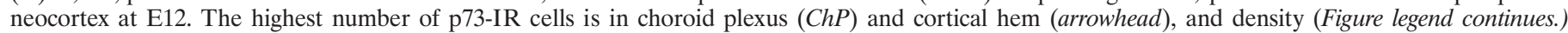




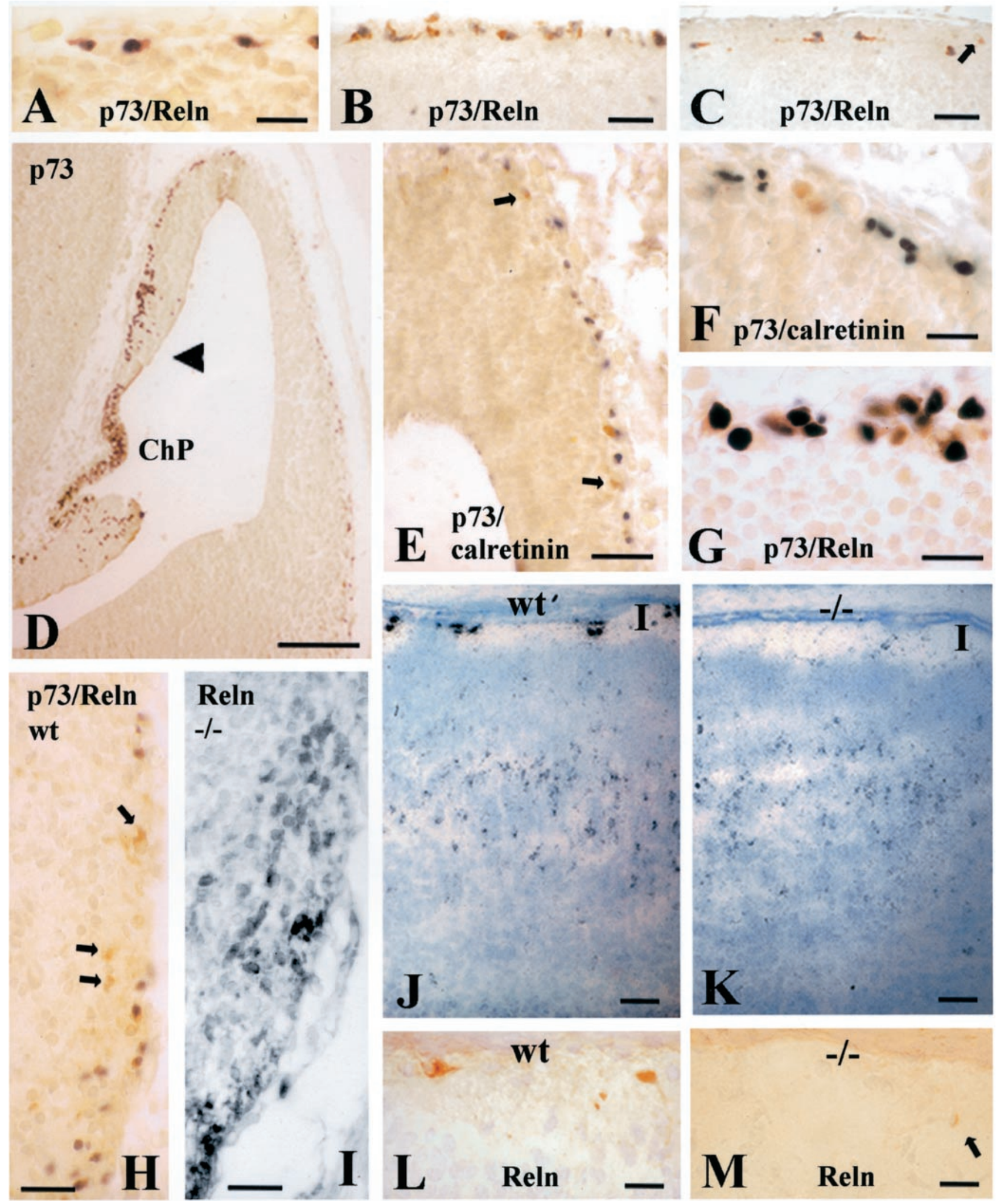

(Figure legend continued.) decreases in the lateral cortical wall. E, In the E12 preplate, a few cells express calretinin (brown, arrows; p73 in black). F, In E12 preplate, calretinin (brown) and p73 (black) usually do not colocalize. G, E12, colocalization of Reln (brown) and p73 (black) in superficial cells of taenia tecta. H, E12, p73 (dark gray) and Reln (brown) are partially dissociated in ventral pallium (arrows point to p73-negative, Reln-positive neurons). I, Reln-IR neurons in the mutant ventral pallium. $J, \mathrm{P} 2 \mathrm{wt} ; K, \mathrm{P} 2 \mathrm{p} 73-/-$ mouse, Reln in situ hybridization. Reln transcripts are similarly distributed throughout layers III-V. The difference is in layer I, where the Reln signal is strong and associated with CR cells in the wt, but weak in the mutant. $L$, Reln-IR CR cells in layer I of P2 wt mouse. $M$, In the P2 p73 - /- mouse, Reln-IR neurons in layer I (arrow) resemble the interneurons proper to postnatal life (compare with Fig. $7 C$ ). Scale bars: $A-C, 25 \mu \mathrm{m} ; D, 110 \mu \mathrm{m} ; E, 30 \mu \mathrm{m} ; F, 25 \mu \mathrm{m} ; G, 15 \mu \mathrm{m} ; H, I, 25 \mu \mathrm{m} ; J, K, 50 \mu \mathrm{m} ; L, M, 20 \mu \mathrm{m}$. 

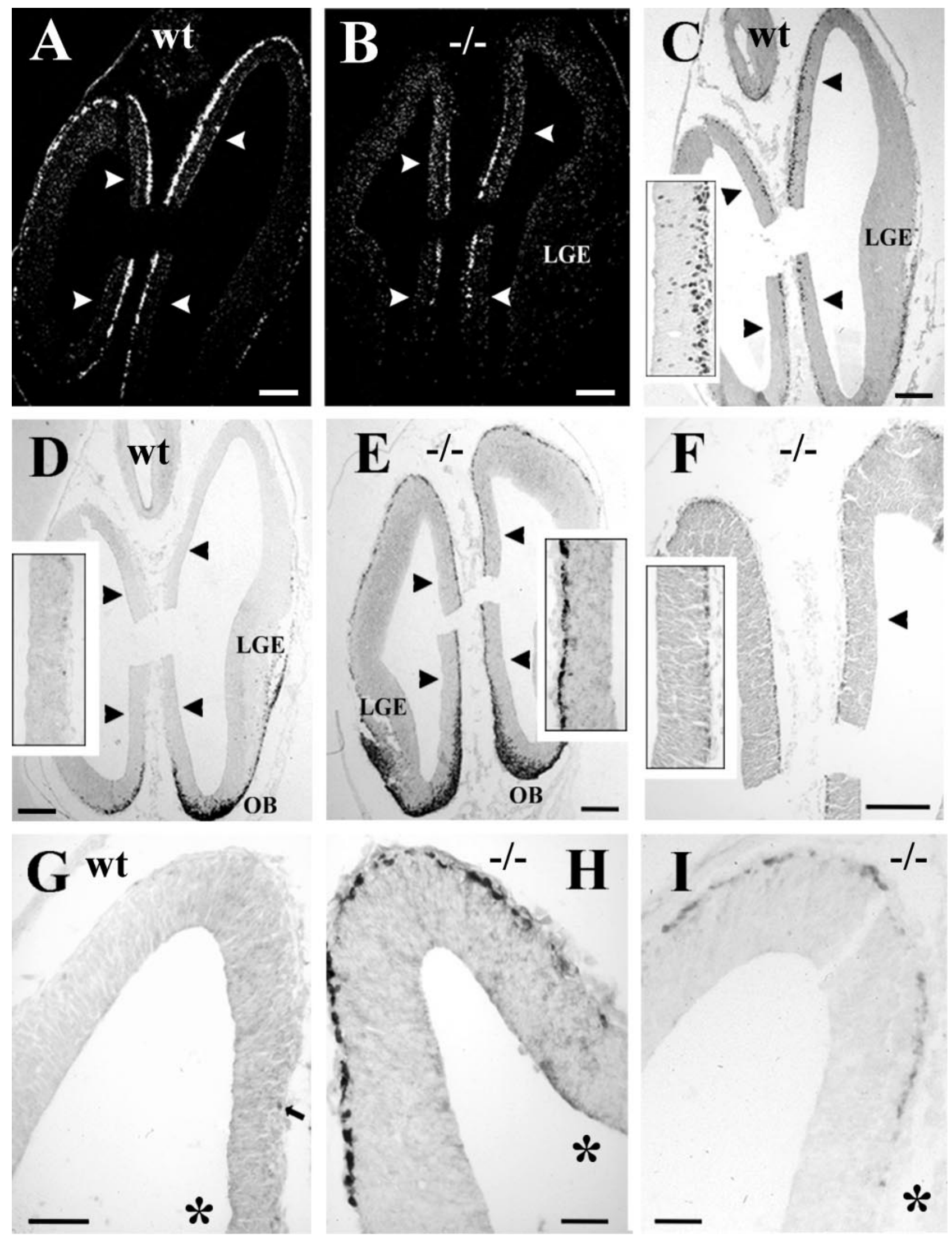

Figure 8. The effects of p73 deficiency on calretinin and reelin expression in the preplate. $A, B$, In situ hybridization using p73 probes in wt ( $A$ ) and mutant $(B)$ cortex at the level of taenia tecta, indicated by arrowheads. In $A$, transcripts are expressed along the entire cortical surface, whereas in $B$ they are restricted to taenia tecta. $C$, Distribution of p73 protein in wt. Inset shows cells in deep ventricular zone of taenia tecta, suggesting local generation. $D$, Calretinin in wt forebrain. Olfactory bulb $(O B)$ and ventral pallium overlaying lateral ganglionic eminence (LGE) (Figure legend continues.) 


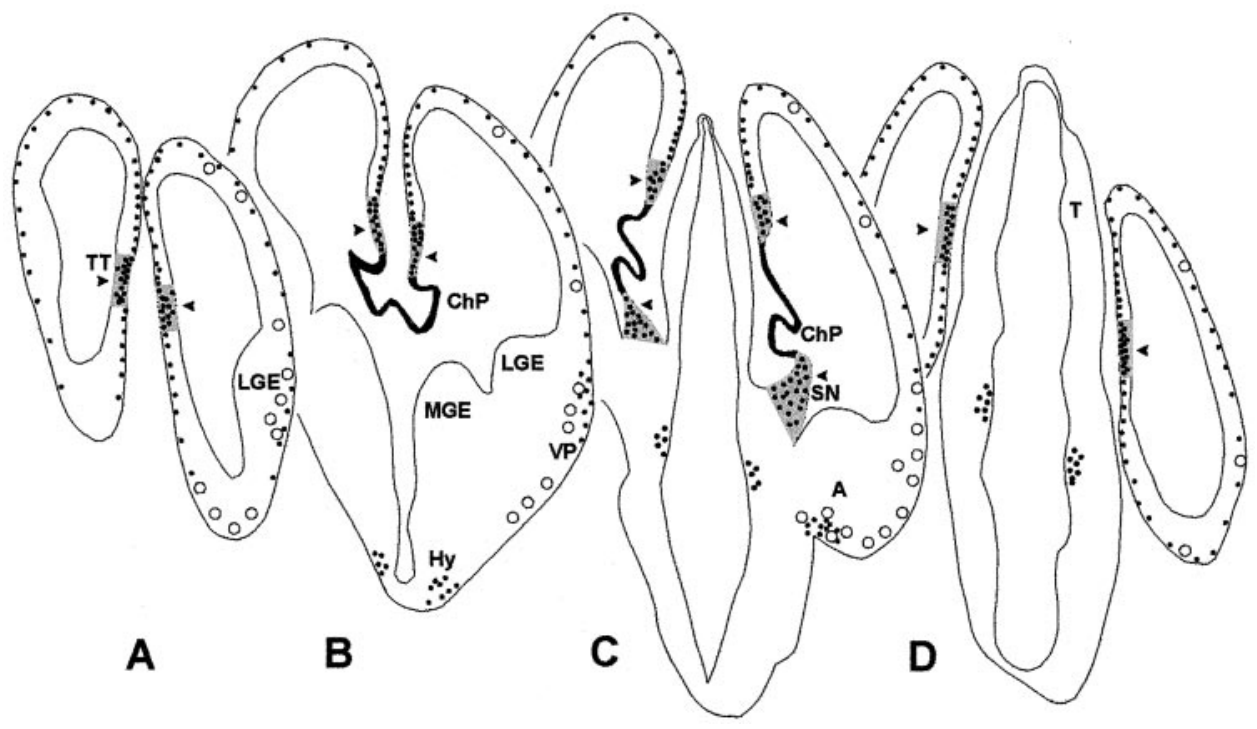

Figure 9. Schematic representation of the distribution of p73-positive cells in E12 mouse brain at various levels from rostral $(A)$ to caudal $(D)$. p73-positive cells are shown as black dots. On the right, Relnpositive, p73-negative cells are represented as open circles, indicating the partial dissociation between $\mathrm{p} 73$ and Reln at this stage. Highest p73 expression is in the choroid plexus (in black). Arrowheads point to those regions (in gray) where p73-IR cells are found in the deep ventricular zone, suggesting local generation. These regions correspond to the cortical-choroid junction or cortical hem in $B$ and $C$, a well as to its rostral $(A)$ and caudal $(D)$ extensions, and to the strionuclear neuroepithelium $(C)$. $A$, amygdala; $C h P$, choroid plexus; $H y$, hypothalamus; $L G E$, lateral ganglionic eminence; $M G E$, medial ganglionic eminence; $L V$, lateral ventricle; $O B$, olfactory bulb; $S N$, strionuclear neuroepithelium; $T$, thalamus; $T T$, taenia tecta; $V P$, ventral pallium. p73 and Reln described in preplate and basal telencephalon of human embryos.

In E12 p73-/- mice, Reln-IR cells in septum, ventral pallium (Fig. 7I), and amygdala displayed similar distributions and staining intensity as in wild-type brain. In the prospective neocortex, antigen retrieval methods revealed a layer of faintly stained Reln-IR neurons in the superficial preplate (Fig. $8 F, I$ ). To answer the question of whether Reln-IR neurons in the mutant and wild-type preplate belonged to the same cell population, we performed in situ hybridization using probes detecting as well normal or disrupted p73 transcripts. In E12 wild-type mice, p73 probes produced a distinct staining extending over the entire cortical surface, ventral telencephalon, and taenia tecta, in accord with the distribution of $\mathrm{p} 73$ protein (Fig. $8 A, C$ ). In the mutants, p73 transcripts were confined to cortical hem and taenia tecta (Fig. 8B). These results indicated that cells expressing p73 transcripts in mutant mice were present at their presumed place of origin, but did not spread farther into neocortical territory, supporting the view that a substantial proportion of CR cells derive from cortical hem and taenia tecta and course into the neocortical primordium through tangential migration. They also demonstrated that the Reln-expressing cells in the mutant and wild-type preplate belonged to different cell populations.

\section{The effects of p73 deficiency on calretinin and reelin expression}

To further characterize Reln-positive preplate neurons, we compared calretinin immunostaining in E12 wild-type and p73deficient mice, because calretinin is considered a marker of $\mathrm{CR}$ cells in rodent cortex (Del Rio et al., 1995). In wild type, calretinin-expression was prominent in olfactory basal forebrain and ventral pallium, but sparse in cortical hem, taenia tecta, and prospective neocortex (Fig. 8D,G), where calretinin-IR neurons were mostly p73-negative (Fig. $7 E, F$ ). By contrast, in the p $73-/-$ mice, a continuous layer of strongly stained calretinin-IR neurons covered the entire preplate and taenia tecta (Fig. $8 E, H$ ), the same territories that also displayed the faint Reln staining. The Reln signal was too weak to be detected in double-labeling experiments using fluorescence microscopy (data not shown), and we could not determine to what extent calretinin and Reln were colocalized in the same cells.

The calretinin- and Reln-positive cells in the mutant neocortical primordium were clearly more numerous than the rare calretinin-positive/p73-negative cells in the wild type; their high incidence, along with the absence of p73 transcripts in this location, suggested that they belonged to a distinct cell population, not present in this form in the wild-type cortex, which may possibly compensate the loss of p73/Reln-expressing CR cells.

At P2, a cell-sparse layer I was clearly recognizable in the mutant. In wild-type mice, high expression of Reln mRNA and protein was mainly localized to large CR cells (Fig. 7I,K). In the mutant, CR cells were undetectable, whereas a weak Reln signal seemed to be associated with small cells, possibly interneurons (Fig. 7J,L), which are a normal cell component of the postnatal molecular layer (Fig. 7C, arrow). In layers III-V, Reln transcripts in wild-type and mutant mice had the same distribution described for Reln-expressing interneurons (Alcántara et al., 1998).

\section{DISCUSSION}

\section{p73 in Cajal-Retzius cells}

The virtually complete co-expression of p73 and Reln in CR cells during cortical migration suggests that the close association between both proteins may be related to specific aspects of the migration period. In contrast to Reln, which is also expressed by interneurons of the CP (Alcántara et al., 1998; Pesold et al., 1999; Perez-Garcia et al., 2001), p73 in cortex is exclusive to CR cells and may be considered a more reliable marker of this cell type.

\footnotetext{
(Figure legend continued.) show strong immunoreactivity, whereas prospective neocortex and taenia tecta (inset, at higher magnification) are practically devoid of calretinin-IR cells. $E$, Calretinin in p $73-/-$ brain. The entire cortical surface and taenia tecta (inset) display a continuous layer of intensely calretinin-IR cells. F, In p73-/- brain, Reln is weakly expressed in superficial preplate and in taenia tecta (inset). $G$, Calretinin in wt cortical hem and dorsal cortex; arrow points to a small positive cell in cortical hem. $H$, Calretinin in mutant cortical hem and dorsal cortex. $I$, Reln in mutant cortical hem and dorsal cortical wall. The asterisks in $G-I$ indicate cortical hem. $A, C$, and $D$ were taken from parallel, closely adjacent sections, similarly as $B, E$, and $F$. Scale bars: $A-F, 120 \mu \mathrm{m} ; G, 50 \mu \mathrm{m} ; H, I, 25 \mu \mathrm{m}$.
} 
Of the various p73 isoforms, $\mathrm{p} 73 \alpha$ and $\Delta \mathrm{N}-\mathrm{p} 73 \alpha$ are the only expression products identified in developing mouse and human brains (Yang et al., 2000) (Caput, unpublished results), with $\Delta \mathrm{N}-\mathrm{p} 73 \alpha$ predominating during embryogenesis (Yang et al., 2000). How might the anti-apoptotic activity of $\Delta \mathrm{N}-\mathrm{p} 73$ possibly relate to $\mathrm{CR}$ cells?

CR cells are exposed to a variety of potential stress factors, such as the permanent turnover of their axonal target in the upper $\mathrm{CP}$ or their separation from the pial surface and descent in the MZ (Meyer et al., 1999). Their characteristic ascending processes may represent an attempt to maintain trophic support from the leptomeninges (Super et al., 1997; Hartmann et al., 1999). TUNEL in situ labeling failed to reveal DNA fragmentation in human CR cells (Spreafico et al.,1999; Rakic and Zecevic, 2000), however, CR cells were described to undergo cytoplasmic cell death (Derer and Derer, 1990). p73 may be involved in determining the fate of CR cells. Because $\Delta \mathrm{N}$-p73 rescues cultured sympathetic neurons from nerve growth factor withdrawal-induced cell death (Pozniak et al., 2000), in vivo, it might also be able to keep CR cells alive under adverse conditions. Downregulation of $\Delta \mathrm{N}$-p73 might be a way of implementing their death at the end of the migration period. The potential ability of p73 to influence CR cell fate may be an important aspect in cortical development: by modulating survival and death of CR cells, p73 may regulate the precise amount of Reln in the MZ required by the migrating $\mathrm{CP}$ cohorts.

\section{The origins of Cajal-Retzius cells}

The specificity of the p73/Reln signal for CR cells strongly suggests that double-positive neurons in the early telencephalon are destined to the cortical MZ. Multiple origins would explain the variety of region-specific genes expressed by CR cells (Lavdas et al., 1999, Mallamaci et al., 2000; Hevner et al., 2001).

In human embryonic brains, p73/Reln expression marks migratory routes of putative CR cells from distinct sectors of the telencephalon. We propose the following sequence of events: (1) Early in development, p73-IR and Reln-IR cells are widely distributed throughout the telencephalon, with a partial dissociation of p73 and Reln. (2) At the preplate stage, a minor CR population courses from MGE to the prospective paleocortex; this may explain the presence of Lhx6, a marker of MGE, in some CR cells (Lavdas et al., 1999). (3) At the onset of CP formation, the cortical hem and taenia tecta give rise to neocortical CR cells, whereas the strionuclear neuroepithelium may provide CR cells for the amygdala. (4) During the protracted period of cortical migration, additional p73/Reln-IR neurons may migrate from the periolfactory forebrain into the neocortical MZ (Meyer and Wahle, 1999), which is compatible with Tbr1 expression by CR cells (Hevner et al., 2001). This mechanism may explain why CR cells still increase in number and packing density from 14 to 18 GW (Meyer and Goffinet, 1998). The origin of p73/Reln-IR neurons in the medial periolfactory forebrain proposed here slightly differs from the source of the SGL described previously in a more lateral position (Brun, 1965; Gadisseux et al., 1992; Meyer and Wahle, 1999). Although SGL-granule cells and p73/Relnpositive cells may use the same tangential migration route from the basal forebrain into the neocortical MZ, they seem to belong to distinct cell populations. This view is in accord with birthdating studies in monkeys showing that SGL cells are generated later than CR cells (Zecevic and Rakic, 2001). Furthermore, neurons from the MGE may travel via the SGL and become cortical interneurons (Wichterle et al., 2001). The human SGL has a complex cell composition, which may change over time, and certainly requires further studies.

The LGE has not been reported as a major source of CR cells, which is consistent with the low level of p73 in LGE of human embryos. The numerous p73-negative, Reln-positive cells in the E12 mouse ventral pallium may not migrate into the MZ but become interneurons of deep cortical layers (Anderson et al., 1997, 2001), or neurons of the striatum.

As a corollary of the multiple origins and migratory waves of p73/Reln-IR cells, there is virtually no moment in life without the presence of Reln in cortex. The finding that the absence of p73/Reln-IR CR cells in the E12 p73-/- mouse is accompanied by the appearance of a distinct Reln-expressing cell population in the neocortical primordium emphasizes the importance of Reln in early cortical development when preplate splitting is initiated (Pearlman and Sheppard, 1996). The origins of the calretinin/ Reln-expressing cell population in the mutant cortex and the mechanisms leading to its presence in the preplate will be addressed in future studies.

\section{The cortical hem as a possible source of neocortical Cajal-Retzius cells}

A contribution of this study is the tangential migration of early CR cells from the cortico-choroid junction or cortical hem into neocortex. The cortical hem is a putative signaling center at the interface of choroid plexus and cortex that directs patterning of the dorsal telencephalon including $\mathrm{HC}$ and is marked by the expression of multiple Wnt genes (Grove et al., 1998).

The neuroepithelium in the medial hemispheric wall is usually related to future $\mathrm{HC}$ and cingulate cortex (Altman and Bayer,1995; Puelles et al., 2000); taenia tecta represents its most rostral extension. In contrast to rodent $\mathrm{HC}$, the adult human $\mathrm{HC}$ is confined to the temporal lobe, and the fetal dorsal $\mathrm{HC}$ regresses in parallel with the emergence of the corpus callosum (Rakic and Yakovlev, 1968). We suggest that the p73-IR cells in cortical hem and taenia tecta are involved in neocortical rather than in hippocampal development.

Several lines of evidence support this hypothesis. First, the timing: the mediolateral migration wave is restricted to a specific developmental stage before the emergence of the dorsal HC. Anatomical markers, such as calretinin and calbindin, identify early cell populations of the human dorsal $\mathrm{HC}$ and allow to define the appearance of hippocampal subfields (Meyer, unpublished observations). When the dorsal HC develops, p73-IR cells in cortical hem dramatically decrease in number, whereas the fornix occupies the ventral portion of the cortical hem.

Second, the mediolateral gradient: from 7 to $10 \mathrm{GW}$, the distribution of CR cells in prospective neocortex follows a pronounced mediolateral gradient, with the highest density in medial wall and the lowest density at the level of the striatocortical angle. Ventral to this reference point, CR cell density increases again, indicating an incipient opposite migration from ventrolateral to dorsomedial that overrides the mediolateral gradient in the following stages (Meyer and Wahle, 1999).

Third, parallels with rodent studies: our findings in man and mouse concur in the almost complete colocalization of p73 and Reln in CR cells during CP migration and in the highest expression of p73 in the cortical hem. The rodent Wnt-rich cortical hem is clearly set apart from the hippocampal neuroepithelium and may be involved in the patterning of the dorsal telencephalon, including both neocortex and archicortex (Grove et al., 1998; Tole and Grove, 2001). Furthermore, recent fate-mapping studies of 
Gdf7-expressing cells identified the dorsal midline region as a potential source of cortical neurons (Monuki et al., 2001). The presence of roof plate-derived cells in the cortical marginal zone is an important precedent for the migration of p73-IR CR cells from cortical hem into neocortex proposed here.

Fourth, the p73-/- mutant: p73-Neo transcripts were observed at the proposed birth place of CR cells, but did not spread into the neocortical primordium, supporting our model that a p73-dependent subset of neocortical CR cells derives from cortical hem and taenia tecta.

\section{Other possible roles of p73 in telencephalic development}

The most evident brain malformation of the p73-/- mouse is a dysgenesis of the infrapyramidal blade of the dentate gyrus (Yang et al., 2000). This part of dentate gyrus may be the most vulnerable to a loss of p73/Reln-expressing hippocampal CR cells, because neurogenesis extends into postnatal life (Bayer, 1980) when the cortical hem has long disappeared. The expression pattern of p73 in cortical hem and choroid plexus may also reflect a role of p73 in area specification within HC.

Analysis of p73 distribution suggests further roles in forebrain patterning and establishment of early boundaries. This view is supported by our finding that p73 is concentrated along major borders, e.g., between choroid plexus and cortical hem, or between strionuclear neuroepithelium-amygdala and hypothalamus. Further studies may show to what extent p73 contributes to the establishment of regional identities in the forebrain and whether this activity is unrelated to the Reln-Dab1 signaling pathway.

\section{REFERENCES}

Alcántara S, Ruiz M, D'Arcangelo G, Ezan F, De Lecea L, Curran T, Sotelo C, Soriano E (1998) Regional and cellular patterns of reelin mRNA expression in the forebrain of the developing and adult mouse. J Neurosci 18:7779-7799.

Altman J, Bayer SA (1995) Atlas of prenatal rat brain development. London: CRC.

Anderson SA, Eisenstat DD, Shi L, Rubenstein JLR (1997) Interneuron migration from basal forebrain to neocortex: dependence on Dlx genes. Science 278:474-476.

Anderson SA, Marin O, Horn C, Jennings K, Rubenstein JLR (2001) Distinct cortical migrations from the medial and lateral ganglionic eminences. Development 128:353-363.

Bayer SA (1980) Development of the hippocampal region in the rat II: morphogenesis during embryonic and early postnatal life. J Comp Neurol 190:115-134.

Brun A (1965) The subpial granular layer of the foetal cerebral cortex in man. Its ontogeny and significance in congenital cortical malformations. Acta Pathol Microbiol Scand 179:1-98.

Cajal SR (1911) Histologie du système nerveux de l'homme et des vertébrés, Vol 2. Paris: Maloine.

D'Arcangelo G, Miao GG, Chen SC, Soares HD, Morgan JI, Curran T (1995) A protein related to extracellular matrix proteins deleted in the mouse mutant reeler. Nature 374:719-723.

D'Arcangelo G, Nakajima K, Miyata T, Ogawa M, Mikoshiba K, Curran T (1997) Reelin is a secreted glycoprotein recognized by the CajalRetzius-50 monoclonal antibody. J Neurosci 17:23-31.

de Bergeyck V, Naerhuyzen B, Goffinet AM, Lambert de Rouvroit C (1998) A panel of monoclonal antibodies against reelin, the extracellular matrix protein defective in reeler mutant mice. J Neurosci Methods 82:17-24.

Del Rio JA, Martinez A, Fonseca M, Auladell C, Soriano E (1995) Glutamate-like immunoreactivity and fate of Cajal-Retzius cells in the murine cortex as identified with calretinin antibody. Cereb Cortex 5:13-21.

Derer P, Derer M (1990) Cajal-Retzius cell ontogenesis and death in mouse brain visualized with horseradish peroxidase and electron microscopy. Neuroscience 36:839-856.

Gadisseux JF, Goffinet AM, Lyon G, Evrard P (1992) The human transient subpial granular layer: an optical, immunohistochemical, and ultrastructural analysis. J Comp Neurol 324:94-114.
Grove EA, Tole S, Limon J, Yip L, Ragsdale CW (1998) The hem of the embryonic cerebral cortex is defined by the expression of multiple Wnt genes and is compromised in Gli3-deficient mice. Development 125:2315-2325.

Hartmann D, De Strooper B, Saftig P (1999) Presenilin-1 deficiency leads to loss of Cajal-Retzius neurons and cortical dysplasia similar to human type 2 lissencephaly. Curr Biol 9:719-727.

Hevner RF, Shi L, Justice N, Hsueh YP, Sheng M, Smiga S, Bulfone A, Goffinet AM, Campagnoni AT, Rubenstein JLR (2001) Tbr1 regulates differentiation of the preplate and layer 6. Neuron 29:353-366.

Hong SE, Shugart YY, Huang DT, Shahwan SA, Grant PE, Hourihane JOB, Martin NDT, Walsh CA (2000) Autosomal recessive lissencephaly with cerebellar hypoplasia is associated with human RELN mutations. Nat Genet 26:93-96.

Howell BW, Hawkes R, Soriano P, Cooper JA (1997) Neuronal position in the developing mouse brain is regulated by mouse disabled-1. Nature 389:733-737.

Jost CA, Marin MC, Kaelin WJ (1997) p73 is a human p53-related protein that can induce apoptosis. Nature 389:191-194.

Kaghad M, Bonnet H, Yang A, Creancier L, Biscan JC, Valent A, Minty A, Chalon P, Lelias JM, Dumont X, Ferrara P, McKeon F, Caput D (1997) Monoallelically expressed gene related to $\mathrm{p} 53$ at 1p36, a region frequently deleted in neuroblastoma and other human cancers. Cell 90:809-819.

Lambert de Rouvroit C, Goffinet AM (1998) The reeler mouse as a model of brain development. Adv Anat Embryol Cell Biol 150:1-108.

Lavdas AA, Grigoriou M, Pachnis V, Parnavelas JG (1999) The medial ganglionic eminence gives rise to a population of early neurons in the developing cerebral cortex. J Neurosci 19:7881-7888.

Mallamaci A, Mercurio S, Muzio L, Cecchi C, Pardini CL, Gruss P Boncinelli E (2000) The lack of Emx2 causes impairment of reelin signaling and defects of neuronal migration in the developing cerebral cortex. J Neurosci 20:1109-1118.

Meyer G (2001) Human neocortical development: the importance of embryonic and early fetal events. Neuroscientist 7:303-314.

Meyer G, Goffinet A (1998) Prenatal development of reelinimmunoreactive neurons in the human neocortex. J Comp Neurol 397:29-40.

Meyer G, Gonzalez-Hernandez T (1993) Developmental changes in layer I of the human neocortex during prenatal life: A DiI-tracing and AChE and NADPH-d histochemistry study. J Comp Neurol 338:317-336.

Meyer G, Wahle P (1999) The paleocortical ventricle is the origin of reelin-expressing neurons in the marginal zone of the fetal human neocortex. Eur J Neurosci 11:3937-3944.

Meyer G, Goffinet AM, Fairen A (1999) What is a Cajal-Retzius cell? $A$ reassessment of a classical cell type based on recent observations in the developing neocortex. Cereb Cortex 9:765-775.

Meyer G, Schaaps JP, Moreau L, Goffinet AM (2000) Embryonic and early fetal development of the human neocortex. J Neurosci 20:1858-1868.

Monuki ES, Porter FD, Walsh CA (2001) Patterning of the dorsal telencephalon and cerebral cortex by a roof plate-Lhx2 pathway. Neuron 32:591-604.

O'Rahilly R, Müller F (1994) The embryonic human brain: an atlas of developmental stages. New York: Wiley-Liss.

Parnavelas JG (2000) The origin and migration of cortical neurones: new vistas. Trends Neurosci $23: 126-131$.

Pearlman AL, Sheppard AM (1996) Extracellular matrix in early cortical development. Prog Brain Res 108:117-134.

Perez-Garcia CG, Gonzalez-Delgado FJ, Suarez-Sola ML, CastroFuentes R, Martin-Trujillo JM, Ferres-Torres R, Meyer G (2001) Reelin-immunoreactive neurons in the adult vertebrate pallium. J Chem Neuroanat 21:41-51.

Pesold C, Liu WS, Guidotti A, Costa E, Caruncho HJ (1999) Cortical bitufted, horizontal, and Martinotti cells preferentially express and secrete reelin into perineuronal nets, nonsynaptically modulating gene expression. Proc Natl Acad Sci USA 96:3217-3222.

Pozniak CD, Radinovik S, Yang A, McKeon F, Kaplan DR, Miller FD (2000) An anti-apoptotic role for the p53 family member, p73, during developmental neuron death. Science 289:304-306.

Puelles L, Kuwana E, Puelles E, Bulfone A, Shimamura K, Keleher J, Smiga S, Rubenstein JLR (2000) Pallial and subpallial derivatives in the embryonic chick and mouse telencephalon, traced by the expression of the genes Dlx-2, Emx-1, Nkx-21, Pax-6 and Tbr-1 J Comp Neurol 424:409-438.

Rakic P, Yakovlev PI (1968) Development of the corpus callosum and cavum septi in man. J Comp Neurol $132: 45-72$.

Rakic S, Zecevic N (2000) Programmed cell death in the developing human telencephalon. Eur J Neurosci 12:2721-2734.

Schiffmann SN, Bernier B, Goffinet AM (1997) Reelin mRNA expression during mouse brain development. Eur J Neurosci 9:1055-1071. 
Sheldon M, Rice DS, D'Arcangelo G, Yoneshima H, Nakajima K, Mikoshiba K, Howell B, Cooper JA, Goldowitz D, Curran T (1997) Scrambler and yotari disrupt the disabled gene and produce a reelerlike phenotype in mice. Nature 389:730-733.

Spreafico R, Arcelli P, Frassoni C, Canetti GG, Rizutti T, Mastrangelo M, Bentivoglio M (1999) Development of layer I of the human cerebral cortex after midgestation: architectonic findings, immunocytochemical identification of neurons and glia, and in situ labeling of apoptotic cells. J Comp Neurol 410:126-142.

Super H, Martinez A, Soriano E (1997) Degeneration of Cajal-Retzius cells in the developing cerebral cortex of the mouse after ablation of meningeal cells by 6-hydroxydopamine. Brain Res Dev Brain Res 98:15-20.
Tole S, Grove EA (2001) Detailed field pattern is intrinsic to the embryonic mouse hippocampus early in neurogenesis. J Neurosci 21:1580-1589.

Yang A, Walker N, Bronson R, Kaghad M, Oosterwegel M, Bonnin J, Vagner C, Bonnet H, Dikkens P, Sharpe A, McKeon F, Caput D (2000) p73-deficient mice have neurological, pheromonal and inflammatory defects but lack spontaneous tumours. Nature 404:99-103.

Wichterle H, Turnbull DH, Nery S, Fishell G, Alvarez-Buylla A (2001) In utero fate mapping reveals distinct migratory pathways and fates of neurons born in the mammalian forebrain. Development 128: $3759-3771$.

Zecevic N, Rakic P (2001) Development of layer I neurons in the primate cerebral cortex. J Neurosci 21:5607-5619. 